\title{
Lambing Rates by Fixed-Time Intrauterine Insemination with Frozen Semen in Seasonally Anestrous Ewes Treated with a Progestogen- Impregnated Sponge or CIDR ${ }^{\circledR}$ Device
}

\author{
Yutaka FUKUI, Hidekuni HIRAI, \\ Koji HONDA, and Kenichi HAYASHI \\ Laboratory of Animal Genetics and Reproduction, \\ Obihiro University of Agriculture and \\ Veterinary Medicine, Obihiro 080, Japan
}

\begin{abstract}
During the non-breeding season (April to July), 187 ewes treated wth either an intravaginal sponge impregnated with medroxyprogesterone acetate (MAP) or a controlled internal drug release $\left(\mathrm{CIDR}^{\circledR}\right)$ device for 9 days and an injection of pregnant mare serum gonadotropin (PMSG) at one day before the cessation of progestogen treatment were inseminated into the uterus by laparoscopy with frozen-thawed semen at fixed-time basis $(36,48$ or $60 \mathrm{~h}$ after the removal of sponge or device). Insemination was also performed at $18 \mathrm{~h}$ after estrus detection as a control. The time to the onset of estrus after $\mathrm{CIDR}^{\circledR}$ treatment was significantly $(\mathrm{P}<0.05)$ earlier (mean: $24.9 \mathrm{~h}$ ) than that in ewes treated with MAP sponge (mean: $30.0 \mathrm{~h}$ ). The percentages of ewes lambing and lambs born per ewe lambing for inseminations at 36,48 and $60 \mathrm{~h}$ were $66.7 \%$ and $1.69 ; 52.0 \%$ and $1.31 ; 46.2 \%$ and 1.75 for MAP-treated ewes, and $33.3 \%$ and $1.50 ; 73.9 \%$ and $1.53 ; 40.9 \%$ and 1.56 for CIDR ${ }^{\circledR}$-treated ewes. For control ewes, they were $59.1 \%$ and 1.62 ; and $47.6 \%$ and 1.90 for MAP and CIDR ${ }^{\circledR}$ treatments, respectively. There was no significant differences in the lambing rates and prolificacy between MAP and $\mathrm{CIDR}^{\circledR}$ treatments and among the insemination times. An optimum time for an intrauterine insemination with frozen-thawed semen appears to be different in the use of MAP sponge (range: 36 to $60 \mathrm{~h})$ and $\mathrm{CIDR}^{\circledR}(48 \mathrm{~h})$. A significant difference in the lambing rate was found among the sheep farms conducting the present study.
\end{abstract}

Key words: Intrauterine insemination, Frozen semen, MAP, CIDR ${ }^{\circledR}$, Sheep.

(J. Reprod. Dev. 39: 1-5, 1993)

$f$ a method of artificial insemination (AI) with

frozen semen on a fixed-time basis can be established [1-5] without lowering lambing rate, estrus detection by teaser rams becomes unnecessary and the mating system would be simplified. However, the timing of a fixed-time AI has differed with the type of semen used (fresh or frozen) [2] and the time of an injection of pregnant mare serum gonadotropin (PMSG) combined after progestogen treatment $[4,6]$. It has been suggested that with frozen-thawed semen an intrauterine AI should be carried out at closer

Accepted for Publication: Oct. 12, 1992

Correspondence: Y. Fukui time to ovulation [5-7].

For induction and synchronization of estrus in the ewes, several hormonal treatments have been proposed, especially intravaginal sponges impregnated with progesterone or synthetic progestogens such as medroxyprogesterone acetate (MAP) and fluorogesterone acetate (FGA). Recently, a new intravaginal device called the controlled internal drug release $\left(\mathrm{CIDR}^{\circledR}\right)$ impregnated with $0.3 \mathrm{~g}$ progesterone has been developed in New Zealand [8]. Maxwell and Barnes [9] compared the effect of FGA sponge and CIDR ${ }^{\circledR}$ on synchronization of estrus and fertility after natural mating and AI with frozen semen, and found that there was 
no difference in the pregnant rates of ewes treated with the sponges or CIDR ${ }^{\circledR}$ s. However, it has been reported that an intravaginal sponge impregnated with progesterone or CIDR ${ }^{\circledR}$ device induce estrus earlier by 8 to $24 \mathrm{~h}$ than MAP sponge [10-12]. Therefore, it has considered that the type of intravaginal devices employed may affect the timing of a fixed-time AI with fresh or frozen semen.

The present study was conducted to clarify the timing of an intrauterine AI with frozen-thawed semen in Suffolk ewes treated with MAP sponges or $\mathrm{CIDR}^{\circledR} \mathrm{s}$ during the non-breeding season.

\section{Materials and Methods}

\section{Animals}

The present study was conducted at 3 sheep farms located in Hokkaido, Japan; The Tawa Field Station (Farm T), Shibechya-cho during April, 1991. The Happy Farm (Farm H), Noboribetsu-shi during June, 1991 and The Shibetsu Sheep Farm (Farm S), Shibetsu-shi during July, 1991. A total of 224 mature (3- to 9-year-old) Suffolk ewes were used at 3 farms (Farms T, H and S: 44, 93 and 87 ewes, respectively).

\section{Treatment}

At each farm, ewes were treated with either 60 mg MAP sponge (The Upjohn International Ltd., Australia) or CIDR ${ }^{\circledR}$ (Eazi-breed, type G: The Carter Holt Harvey Plastic Products Ltd., New Zealand) for 9 days, and an intramuscular injection of 600 IU PMSG (Serotropin: Teikokuzoki Co., Japan) was administered to the ewes one day before the removal of the sponges and $\mathrm{CIDR}^{\circledR} \mathrm{s}$.

The ewes treated with either MAP sponge or CIDR $^{\circledR}$ device were further devided into 4 groups at each farm and inseminated on a fixed-time basis or at detected estrus (control). The fixed-time intrauterine AI was performed at 36,48 or $60 \mathrm{~h}$ after the removal of MAP sponge and CIDR ${ }^{\circledR}$. For control ewes, inseminations were performed at 18 $\mathrm{h}$ after estrus detection. For detection of estrus, the ewes were run together with teaser rams fitted with a marking harness and crayon and an apron to avoid natural service. Estrus was examined by the crayon mark at $6 \mathrm{~h}$ intervals for 4 days after the progestogen treatment.

\section{Insemination}

Semen was collected, with an artificial vagina, from 5 to 10 rams at each farm and only fresh ejaculates of good initial motility (over $80 \%$ forward movement) and a concentration of at least $25 \times 10^{9}$ spermatozoa $/ \mathrm{ml}$ ) (determined by haemocytometer) were used for freezing. Semen was diluted 1: $4(\mathrm{v} / \mathrm{v})$ at $30 \mathrm{C}$ with a diluent containing Tris (hydroxymethyl) aminomethane $(300 \mathrm{mM})$, glucose $(27.75 \mathrm{mM})$, citric acid $(94.75$ $\mathrm{mM})$, egg yolk ( $15 \%$, v/v) and glycerol $(5 \%, \mathrm{v} / \mathrm{v})$. Freezing, pelleting and thawing procedures were carried out according to the methods of Salamon and Visser [13] and Fukui [14]. After thawing in dry and clean beaker $(20 \mathrm{ml})$ at $37 \mathrm{C}$, the percentage of motile spermatozoa was determined before insemination. A minimum level of $40 \%$ motility was acceptable.

For each insemination, $0.1 \mathrm{ml}$ of frozen-thawed semen containing 50 to $80 \times 10^{6}$ spermatozoa per the uterine horn $(0.2 \mathrm{ml}$ per ewe) was deposited into the uterus using the Cassou insemination pipet (I.M.V., France) with the aid of laparoscopy. The method for intrauterine AI was according to that reported by Maxwell et al. [2].

\section{Statistical analysis}

Data on lambing rate and prolificacy were analyzed by analysis of variance using the general linear models (GLM) procedure of SAS (Statistical Analysis System). Differences among the treatment, insemination times and farms were also analyzed by Tukey's $\omega$-procedure.

\section{Results}

At the time of the removal of the synchronization devices, it was found that $12(1,1$ and 10 ewes for Farms T, H and S, respectively) and 18 (3 and 15 ewes for Farms $\mathrm{H}$ and S, respectively) ewes out of $112(10.7 \%)$ and 112 ewes $(16.1 \%)$ treated with MAP sponges and CIDR $^{{ }^{\circledR}}$ S respectively, had lost the devices during the insertion period. These 30 ewes were therefore eliminated from the present study.

The estrus of the control ewes treated with either MAP sponge or CIDR ${ }^{\circledR}$ device was detected in $23(92.0 \%)$ and $21(91.3 \%)$ ewes out of 25 and 23 ewes, respectively. The onset of estrus in ewes 
Table 1. Lambing results of ewes inseminated with frozen semen at fixed-time basis after treatment of either MAP sponge or CIDR $^{\circledast}$ device

\begin{tabular}{lcccc}
\hline $\begin{array}{l}\text { Insertion } \\
\text { device }\end{array}$ & $\begin{array}{c}\text { Insemination } \\
\text { time*1 }\end{array}$ & $\begin{array}{c}\text { No. of ewes } \\
\text { inseminated }\end{array}$ & $\begin{array}{c}\text { No. of ewes } \\
\text { lambed (\%) }\end{array}$ & Prolificacy \\
\hline MAP sponge & 36 & 24 & $16(66.7)$ & 1.69 \\
& 48 & 25 & $13(52.0)$ & 1.31 \\
& 60 & 26 & $12(46.2)$ & 1.75 \\
& at estrus*2 & 22 & $13(59.1)$ & 1.62 \\
& Sub-total & 97 & $54(55.7)$ & 1.59 \\
\hline $\mathrm{CIDR}^{\circledR}$ & 36 & 24 & $8(33.3)$ & 1.50 \\
& 48 & 23 & $17(73.9)$ & 1.53 \\
& 60 & 22 & $9(40.9)$ & 1.56 \\
& at estrus*2 & 21 & $10(47.6)$ & 1.90 \\
& Sub-total & 90 & $44(48.9)$ & 1.61 \\
\hline & Total & 187 & $98(52.4)$ & 1.60 \\
\hline
\end{tabular}

${ }^{* 1}$ : Hours after the removal of MAP sponge or CIDR ${ }^{\circledR}$.

${ }^{*}$ : Insemination was performed $18 \mathrm{~h}$ after estrus detection.

treated with $\mathrm{CIDR}^{\circledR}$ was significantly $(\mathrm{P}<0.05)$ earlier (mean \pm SEM: $24.9 \pm 1.5 \mathrm{~h}$ ) than that of ewes treated with MAP sponge $(30.0 \pm 1.5 \mathrm{~h})$. At the fixed-time insemination, it was not possible to deposit frozen-thawed semen into the uterus of 4 ewes due to a covering of heavy fat tissue, and these ewes were excluded from the experimental data. A total of 190 ewes were successfully inseminated into the uterus at 3 farms (Farms T, H and S: 43,87 and 60 ewes, respectively). However, 1 and 2 inseminated ewes at Farms $\mathrm{H}$ and $\mathrm{S}$ respectively, died due to unknown causes before lambing. Therefore the final numbers of ewes available for lambing was 187 (Table 1). The lambing rates of the ewes inseminated on the basis of estrus detection were 59.1 and $47.6 \%$ for MAP sponge and $\mathrm{CIDR}^{\circledR}$ treatments, respectively, and the figures were not significantly different. For the lambing rates of ewes inseminated on a fixed-time basis, there were no significant differences in the MAP-treated ewes $(66.7,52.0$ and $46.2 \%$ for 36 , 48 and $60 \mathrm{~h}$ after treatment, respectively), whereas in CIDR $^{\circledR}$-treated ewes the insemination at $48 \mathrm{~h}$ after the removal of CIDR ${ }^{\circledR}$ resulted in the highest rate $(73.9 \%)$ of lambing, but this figure was not significantly different from those in ewes inseminated at $36(33.3 \%)$ and $60 \mathrm{~h}(40.9 \%)$ after treatment. Overall, no significant differences were found between the fixed-time and 'at estrus' inseminations. Differences in prolificacy between
Table 2. Lambing results of ewes inseminated with frozen semen at three sheep farms

\begin{tabular}{cccc}
\hline Farms & $\begin{array}{c}\text { No. of ewes } \\
\text { inseminated }\end{array}$ & $\begin{array}{c}\text { No. of ewes } \\
\text { lambed (\%) }\end{array}$ & Prolificacy \\
\hline $\mathrm{T}$ & 43 & $18(41.9)^{\mathrm{a}}$ & 1.39 \\
$\mathrm{H}$ & 86 & $44(51.2)$ & 1.77 \\
$\mathrm{~S}$ & 58 & $36(62.1)^{\mathrm{a}}$ & 1.56 \\
Total & 187 & $98(52.4)$ & 1.60 \\
\hline
\end{tabular}

a: Significantly different $(P<0.05)$.

groups were also not significant.

The lambing results of the inseminated ewes at three farms were shown in Table 2. There was a significant $(\mathrm{P}<0.05)$ difference in the lambing rate between Farms $\mathrm{T}$ and $\mathrm{S}$, but differences in prolificacy were not significant among the farms.

\section{Discussion}

The present results showed that $\mathrm{CIDR}^{\circledR}$ treatment induced estrus significantly earlier than MAP sponge treatment. Other workers have also reported that an intravaginal sponge impregnated with progesterone or CIDR $^{\circledR}$ device induces estrus earlier by 8 to $24 \mathrm{~h}$ than MAP sponge [10-12]. The onset of estrus in ewes treated with progestogenimpregnated intravaginal sponge was also in- 
fluenced by the time of a PMSG injection [3-5, 15]. In the present study, PMSG was administered one day before the cessation of progestogen treatment. In most of the studies using MAP or FGA sponges [3, 16-18], PMSG was administered at the day of sponge removal, and the time of the onset of estrus after treatment was extended with a range of 12 to $72 \mathrm{~h}$ in the above studies. The difference in times to the onset of estrus after different progestogen treatments may affect the efficacy of a fixed-time insemination.

Similar rates of lambing were obtained by AI at 36,48 and $60 \mathrm{~h}$ after treatment of MAP sponge. On the other hand, with $\mathrm{CIDR}^{\circledR}$ treatment there tended to be that a higher rate of lambing $(73.9 \%)$ was obtained by AI at $48 \mathrm{~h}$ than the AIs at 36 and $60 \mathrm{~h}$. Maxwell [3] reported similar rates of lambing $(45.9,55.1$ and $57.4 \%)$ for fixed-time intrauterine AI with frozen semen at 48, 60 and $72 \mathrm{~h}$, respectively after FGA sponge and PMSG injection at the time of sponge removal. In contrast, Findlater et al. [19] found that the ewes treated with PMSG at FGA sponge removal and inseminated at $48 \mathrm{~h}(62 \%)$ and $60 \mathrm{~h}(63 \%)$ after the sponge removal had a significantly higher lambing rate than ewes inseminated at $72 \mathrm{~h} \mathrm{(44 \% ).} \mathrm{Epples-}$ ton et al. [5] also found a decreased fertility when PMSG was given early (one day before MAP sponge removal) and AI was delayed to $72 \mathrm{~h}$ after the sponge removal. Maxwell and Barnes [9] compared the effect of FGA sponge and CIDR ${ }^{\circledR}$ device on lambing rate and obtained similar rates of pregnancy ( 60 and 54\%, respectively). by an intrauterine $\mathrm{AI}$ at $60 \mathrm{~h}$ after sponge removal. The difference in data between the present study and the study of Maxwell and Barnes [9] is most likely related to the different timing of PMSG injection. Therefore, it is concluded that the optimum time for a fixed-time AI depends on the time of PMSG injection as well as the type of progestogen sponge of device.

A range of the fixed-time AI with frozen semen in ewes treated with MAP or FGA sponge and PMSG at the sponge removal is generally 48 to 60 $\mathrm{h}[3,9,17-20]$. In the present study, PMSG was given one day before the removal of MAP sponge. It has been demonstrated that a PMSG injection one day or two days before the sponge removal induced an earlier onset of estrus as compared with that at the time of sponge removal [4-6]. This would cause a high rate of lambing $(66.7 \%)$ by the
AI at $36 \mathrm{~h}$, although the rate was not significant with those at $48(52.0 \%)$ and $60 \mathrm{~h}(46.2 \%)$. Eppleston et al. [5] showed that a peak of luteinizing hormone and ovulation occur earlier in ewes given PMSG one day before the removal of MAP sponge. From the present study, it appears that an optimum time for a fixed-time intrauterine AI with frozen semen is between 36 and $60 \mathrm{~h}$ when PMSG was administered one day before the removal of MAP sponge, and it is around $48 \mathrm{~h}$ when CIDR $^{\circledR}$ devices were used. This might indicate that the $\mathrm{CIDR}^{\circledR}$ was more precise for the onset of estrus than the sponge.

In the present study, a difference in lambing rate was found between the 2 sheep farms (Farms $T$ and S). In previous study [21] conducted at the same 3 farms, the lambing rate of ewes treated and inseminated with fresh-undiluted semen during the non-breeding season were higher in Farms $\mathrm{S}$ $(61.7 \%)$ than those in Farms $\mathrm{T}(50.0 \%)$ and $\mathrm{H}$ (33.7\%). In that study, the body condition score of ewes in Farm H was significantly lower than those in Farms $T$ and S. Therefore, the present result of a low rate of lambing in Farm $T$ is probably relating to the nutritional status of ewes and rams used [19] on each farm, and seasonality of conducting the present study (April and July for Farms $T$ and $S$, respectively). It is generally considered that April to June is the most quiescent stage of estrous activity of ewes. July is a closer to the commencement of the breeding season which usually occurs about mid-August in Suffolk ewes. The losses of both MAP sponges and CIDR $^{\circledR}$ device were comparatively high (10.7 and $16.1 \%$, respectively) in the present study. Especially, on Farm $S$ where 25 out of 87 ewes treated with either MAP sponge or CIDR ${ }^{\circledR}$ lost their devices during the 9 days of insertion. There was no obvious reasons for the high percentage of losses.

In conclusion, the timing of a fixed-time intrauterine AI with frozen semen may vary according to the use of MAP sponge and CIDR ${ }^{\circledR}$ device, because of the earlier time of the onset of estrus by the latter treatment. It is considered from the present study that with the CIDR ${ }^{\circledR}$ device, more than $70 \%$ of lambing rate can be expected by an intrauterine AI with frozen semen at $48 \mathrm{~h}$ after the treatment in ewes during the late anestrous season. 


\section{Acknowledgments}

The authors thank the staff at 3 sheep farms for the use of animals and facilities, Dr. S.H. Langford, The Upjohn International Ltd., Australia and The Carter Holt Harvey Plastic Products Ltd., New Zealand for the supply of MAP sponges and CIDR $^{\circledR}$ s, respectively. Dr. J.F. Smith, Ruakura Agricultural Centre, MAF Technology, New Zealand is also thanked for reading the manuscript and his valuable comments.

\section{References}

1. Killen ID, Caffery GJ. Uterine insemination of ewes with the aid of a laparoscope. Aust Vet J 1982; 59: 95 .

2. Maxwell WMC, Butler LG, Wilson HR. Intrauterine insemination of ewes with frozen semen. $J$ Agric Sci, Camb 1984; 102: 233-235.

3. Maxwell WMC. Artificial insemination of ewes with frozen-thawed semen at a synchronized oestrus. 1. Effect of time of onset of oestrus. 1. Effect of time of onset of oestrus, ovulation and insemination on fertility. Anim Reprod Sci 1986; 10: 301-308.

4. Akaike M, Fukui Y, Ueda H, Kobayashi K, Ono H. Timed artificial insemination of frozen ram semen separated by bovine serum albumin sedimentation method. Jpn J Anim Reprod 1989; 35: 236-240 (In Japanese).

5. Eppleston J, Evans G, Roberts EM. Effect of time of PMSG and GnRH on the time of ovulation, LH secretion and reproductive performance after intrauterine insemination with frozen ram semen. Anim Reprod Sci 1991; 26: 227-237.

6. Fukui Y, Akaike M, Anzai H, Ono H. Effect of timing of injection with pregnant mare's serum gonadotrophin on fixed-time artificial insemination of seasonally anoestrous ewes. J Agric Sci, Camb 1989; 113: 361-364.

7. Maxwell WMC, Hunton JR, Ryan JP, Hood G. Effect of GnRH on time of ovulation in superovulated Merino ewes. Proc 18th Ann Conf Aust Soc Reprod Biol 1986; 18: 20.

8. Welch RAS, Andrews WD, BArnes DR, Bremner K, Harvey TG. CIDR dispensers for oestrus and ovulation control in sheep. Proc 10th Int Congr Anim Reprod E A.I. 1984; II: 354.

9. Maxwell WMC, Barnes DR. Induction of oestrus in ewes using a controlled internal drug release device and PMSG. J Agric Sci, Camb 1986; 106: 201-203.

10. Fukui Y, Testuka $M$, Akaike $M$, Machiyama $K$, Ono H. Effects of type of vaginal sponge impregnated with progestogen on estrus induction and lambing rate in seasonally anestrous ewes. Jpn J Anim Reprod 1987; 33: 181-187.

11. Rhodes L, Nathanielsz PW. Comparison of a controlled internal drug release device containing progesterone with intravaginal medroxyprogesterone sponges for estrus synchronization in ewes. Theriogenology 1988; 30: 831-836.

12. Smith JF, Parr J, Mortimer BJ. Comparison of two intravaginal devices on the reproductive performance of Coopworth ewes throughout the year. Proc 21st Ann Conf Aust Soc Reprod Biol 1989; 21 : 97.

13. Salamon S, Visser D. Effect of composition of Tris-based diluents and of thawing solution on survival of ram spermatozoa frozen by the pellet method. Aust J Biol Sci 1972; 25: 605-618.

14. Fukui Y. Effects of diluents, thawing temperatures and materials of thawing containers on survival of ram spermatozoa frozen by the pellet method. Jpn J Anim Reprod 1979; 25: 160-169.

15. Roche JF. Effect of the interval between withdrawal of progestagen pessaries and time of PMS administration on oestrus and ovulation in cyclic ewes. Ir J Agric Res 1968; 7: 1-6.

16. Evans G, Robinson TJ. The control of fertility in sheep: endocrine and ovarian responses to progestagen-PMSG treatment in the breeding season and in anoestrus. J Agric Sci, Camb 1980; 94: 69-88.

17. Hunton JR, Flecker SE. Pregnancy rates following intra-uterine insemination with pellet or strawfrozen ram semen. J Agric Sci, Camb 1987; 109: 189-191.

18. Aitken RP, Wallace JM, Robinson JJ. A note on conception rates and litter sizes following the intrauterine insemination of ewes at an induced oestrus during seasonal anoestrus. Anim Prod 1990; 50: 379-382.

19. Findlater RCF, Harrsign W, Curnock RM, BEck NFG. Effect of timing of intrauterine insemination with frozen-thawed semen on fertility in ewes. Proc 11th Int Congr Anim Reprod E A.I. 1988; 3: 242.

20. Halbert GW, Dobson JS, Walton JS, Sharpe P, Buckrell BC. Field evaluation of a technique for transcervical intrauterine insemination of ewes. Theriogenology 1990; 33: 1231-1243.

21. Fukui Y, Yamamoto Y, Goda S, Ono H. Single or double inseminations at fixed-time basis on lambing rate of ewes treated with progestogenimpregnated intravaginal sponges during the nonbreeding season. Jpn J Anim Reprod 1991; 37: 231-235. 